\title{
ADULTERY CHILD STATUS IN ISLAMIC LAW AND IN THE CIVIL CODE
}

\author{
Hari Sutra Disemadi \\ Faculty of Law, Diponegoro University, Semarang, Indonesia \\ Email: haridisemadi@gmail.com
}

\begin{abstract}
Problems regarding the status of children born outside of legal marital relations are still interesting discussions. In the community the status of children is often questioned, because not a few children are born without marriage. So from this this study will focus on the status of illegitimate children in Islamic law and in the Civil Code. The research method used is a normative juridical research method based on secondary data, namely primary legal material, secondary legal material and tertiary legal material. This research shows that in Islamic law and Civil Code the legitimate denial of children can result in the breakup of marriage making the child an illegitimate child and not having an inheritance relationship with his parents, but his mother according to Islamic law. If the child of adultery is associated with obligations and responsibilities regarding survival, then the parents or fathers are still charged with the obligation to provide a living. As the cost of living and the cost of their education as needed or according to their abilities, because he is the biological father of the child. If the status of the adultery child is associated with inheritance according to BW, then he does not inherit at all to the two tunya people. but if it is associated with Islamic inheritance, then he inherits only his mother and his mother's family.
\end{abstract}

Keywords: Adultery Child, Islamic Law, Civil Code

\section{Introduction}

It has become nature and character in life, that humans have a tendency to relate to one another. The tendency appears naturally, along with the existence of life necessities that will only be fulfilled if there is mutual interaction 
between one person and another. ${ }^{1}$ According to Zakiah Daradjat, arguing that the existence of these needs, both primary, namely physical needs such as the need to eat, drink, sexual and so on, and needs that are spiritual (psychic, social) have encouraged humans to interact and socialize with each other, both association is temporary and continuous. ${ }^{2}$

At present, in the midst of association, men and women tend to use the attributes of freedom in their lives, so in this relationship Islamic shari'a with its universal values provides direction and guidance in their association. Samih Athif az-Zain explains about relationships in the family environment that, the relationship between men and women, and the relationship of women and men in sexual terms, is a natural relationship and does not contain oddities, it is even an original relationship only with it did the goal materialize, for which this instinct was held. That is the continuity of type, while the pleasure and enjoyment obtained in fulfillment are natural and must be considered by humans or not. ${ }^{3}$

Meanwhile, according to Munandar Soelaeman, the existence of men and women in society has its own value among other creatures, because as moral beings, social beings, ethical beings, morals, are used as moral barometers in people's lives, humans as social beings cannot stand alone, must be able to adjust to the norms of personality and the views of life adopted by the community and the nation, that means it implies that they do not make relations and associate freely, but he has responsibility for himself, towards family and society general, also specifically responsibility towards God. ${ }^{4}$

If humans are approached individually, not only have responsibility for society and the environment, but he must be aware that he is the vicegerent of God on this earth, meaning that the Caliph must be able to live the rules of life desired by Islamic law, so that what is done by humanity is a tangible manifestation of his service to God. ${ }^{5}$

In society, the issue of child status is often questioned even though formally or legally written legally only applies in all regions of Indonesia, for example the legal system adopted by the Civil Code (KUH Perdata / BW),

1 Ali Mohtaron. Kedudukan Anak Hasil Hubungan Zina Menurut Hukum Islam Dan Hukum Positif. Al-Murabbi: Jurnal Pendidikan Agama Islam. Volume 3 Nomor 2 Juni 2018, 193-203, p. 195

2 Imam Juhari. Legal Guardianshio Of Adultery Child And The Right Of Inheritence. Kanun Jurnal Ilmu Hukum, Nomor 4 Agustus 2011, 1-20, p. 17

3 Agussalim Andi Gadjang. Kedududkan Anak Di luar Pernikahan Menurut KUH Perdata dan Menurut Hukum Islam. Junal Asy-Syir'ah. Volume 45 Nomor 1 tahun 2011, 1221-1234, p. 1229

4 Ali Mohtaron. Op.Cit., p. 197

5 Imam Juhari. Op.Cit., p. 19 
especially in the rules of Article 251 affirmed that: "The validity of a child born before the hundredth day of eighty in the marriage of a husband and wife can be denied by the husband".

From the system adopted by BW, it is not different from the one adopted by Islamic sharia (Islamic Law). The scholars have agreed, that a child is born less than six months after marriage, so the child is an illegitimate child (adultery child) and cannot be related nasab and inheritance to his father. Based on the provisions adopted by BW and Islamic Law, when connected in reality in everyday life among the people today, it is found that there is free association between a man and a woman who is very contrary to the norms of decency and norms of Islam. As a result of an adultery that creates a pregnancy, ${ }^{6}$ it is usually mated to legalize the baby in the womb, or who has been born so that he favors, which is more surprising when there is a community between a man and a woman living together as husband and wife without marriage and has given birth to a child or several children. Sometimes also in the life of a husband and wife there is a child who is not recognized by his father as his child. ${ }^{7}$

Previous research that focused on the position of illegitimate children was conducted by Imam Jauhhari in 2011 with the research title "Legal Guardianship of Adultery Child and Right of Their Inheritence" published on Kanun Jurnal Ilmu Hukum. Maria Ulfah in 2015 with the research title "Wanita Hamil Di Luar Nikah (Status Anak)" published on Jurnal Pembaharuan Hukum, and Ali Mohtaron in 2018 with the research title "Kedudukan Anak Hasil Hubungan Zina Menurut Hukum Islam Dan Hukum Positif' published on AlMurabbi: Jurnal Pendidikan Agama Islam.

Based on previous research, although they both took the theme of research on illegitimate children, in this study the focus was on the position of illegitimate children in the perspective of the Civil Code and the perspective of Islamic Law. Based on the focus of the research, the problem in this research is how the position of children outside marriage according to the Civil Code and according to Islamic Law?.

\section{Research methods}

The method used in this writing is a normative juridical writing method, namely in the form of library research, which is a method of writing used by studying literature books, legislation. This writing uses a systematic and directed method using the law as a legal basis as well as guidelines for analysis. The whole series of writing activities is basically aimed at gathering legal

$6 \quad$ Ali Mohtaron. Op.Cit., p. 200

7 Maria Ulfah. Wanita Hamil Di Luar Nikah (Status Anak). Jurnal Pembaharuan Hukum. Volume 2 Nomor 3 Desember 2015, 329-335, p. 331 
material, then the material is processed and linked to legal concepts, and the results obtained are expressed in the form of juridical thinking. The data for this writing is obtained through the primary legal material of legislation, and secondary legal materials, namely in the form of textbooks by legal experts.

\section{Discussion}

\section{Understanding Adultery}

Marriage is an important event in human life that causes legal consequences both on the relationship between the parties that carry out the marriage itself, as well as with other parties who have certain interests. If the child is born from the marriage, then a legal relationship arises between the child and his parents. ${ }^{8}$

Adultery children in the Dutch language "bestaard"; in English "bestard"; in zandah "haram"; sundel child; and subang child. Besides the definition of western law $(\mathrm{BW})$, in Islamic law there are many scholars who provide understanding of adultery, among them according to Al Jurjani stated: Inserting a penis (penis) into the vagina is not his (not his wife) and there is no element of syubhat (similarity and error). ${ }^{9}$

From the definition it can be understood that an act can be said to be adultery if it fulfills two elements, namely: ${ }^{10} 1$ ). The existence of intercourse (sexual intercourse) between two people of different sexes (hiterosex); and 2). Absence of similarity or error (Syubhat) in sex act. So zina children, according to Islamic law are children born because of the relationship between a man and a woman without a legal marriage contract, including children born before up to six months from the marriage contract of his father's mother.

In civil law and in Islamic law the child is divided into two parts, namely legal children and illegitimate children:

\section{Legitimate children according to the Civil Code (KUH Pertada) and Islamic Law}

In the Civil Code, especially in the rules of Article 250 it has been clearly stated, that a legitimate child is "each child born or grown throughout marriage, obtaining the husband as his father". the rules of the Republic of

8 Busman Edyar. Status Anak Luar nikah Menurut Hukum Positif dan Hukum Islam Pasca Keluarnya Putusan MK Tentang Uji materiil Undang Undang Perkawinan. Al Istinbath: Jurnal Hukum Islam. Volume 1 Nomor 2 Tahun 2016, 1-28, p. 8

9 Agussalim Andi Gadjang. Op.Cit., p. 1231

10 Dzanurusyamsi. Upaya Pengadilan Dalam Perlindungan Anak Luar Nikah Berdasarkan Sila Ke-5 Pancasila. Jurnal Pembaharuan Hukum. Volume 3 Nomor 1, April 2016, 86-97, p. 89 
Indonesia Number 1 of 1974 concerning Marriage, especially in the rules of Article 42 are regulated and affirmed, that a legitimate child is a child born in a legitimate marital condition, so that a legitimate child is a child born or raised in in marriage, even though the child who is born takes place in a very short time when a marriage is held, and in the Civil Code it is also known that the term child is legitimately recognized and the child is legalized. In that regard, the rules or norms set forth in in the Civil Code there are four classifications of children, namely: 1). Natural Child; 2). Recognized Child; 3). Legalized Child; 4). Child Sah. That is a natural child who has been acknowledged by his father or mother as his child, if this child is acknowledged by his parents, then the child has a relationship the law between father and mother. Legalized children, namely children who after being recognized as children by their mother's father, are legally legalized as their children, provided that their father and mother must first complete marriage. With the certificate of ratification, the legal position of the approved child becomes the same or equal to the legal child. The legal consequences of ratifying a child are the same as those of a legitimate child born in marriage. ${ }^{11}$

The definition of a child is legal according to Islamic law, as that child is a gift from Allah SWT, which should be grateful for every faithful person who is obtained through a legitimate marriage because there is a combination of men and women through a legitimate marriage, then practically give birth to a baby later as a legitimate child. From this, then according to Sayyid sabiq in his book fiqhus sunnah implies that "if a woman gives birth to a child when she has just been married for six months, then she may not be accused of adultery, and should not be sentenced".

Furthermore, according to Asaf A.A. Pyzee stated that the legitimacy of a child born according to Islamic law is: 1). A child born for six months from marriage days is not valid except that if the father recognizes the born as his child; 2). A child who has been valid for six months from the wedding day, except the siblings, does not admit it; and 3). A child born after the interruption of marriage is valid if within 10 months he is born according to the Arab month and Shari'ah law. ${ }^{12}$

From some of the meanings stated above, it gives an understanding that legal children according to Islamic law are children who are grown or cultured as a result of legal marriage. Furthermore, in Islamic law it is regulated also regarding the deadline for legal certainty of whether or not a child, but textually in the Qur'an is not explicit, but can be understood as stated in Al-Qur'an AlAlqaf verse 15, which is associated with surah Al-Baqarah verse 233 which

11 Agussalim Andi Gadjang. Op.Cit., p. 1236

12 Agussalim Andi Gadjang. Ibid., p. 1237 
reads: "Kami perintahkan kepada manusia supaya berbuat baik kepada dua orang ibu bapaknya, ibu yang mengandungnya dengan susah payah, dan melahirkan dengan susah payah (pula). Mengandung sampai menyepihnya adalah 30 bulan ... (Al Ahqaf: 15)" And the surah Al Baqarah verse 233 reads: "Para ibu hendaklah menyusukan anaknya selama 2 tahun penuh, yaitu bagi orang yang ingin menyempurnakan penyusuan ...".

From the two verses above, the commentators provide interpretations including: According to Ibn Abbas, he stated that the verse gives an understanding that is, if a woman is pregnant for 9 months, she is breastfeeding for 21 months, and if she is pregnant for six months, then breastfeeding for 24 months. Furthermore, Al-Maraghy stated, that the minimum time to conceive is that the amount of 30 months is reduced by breastfeeding for 24 months, so the milk is six months that is the minimum period of pregnancy. ${ }^{13}$

From the two verses and the two interpreting scholars who stated about a mother's pregnancy period, both the maximum and the minimum limit, it can be understood if less than the minimum determined period, the child born is considered an illegitimate child according to Islamic law, but when appropriate with the specified time limit, the child is considered valid according to Islamic law. So both the Civil Code and in Islamic law consider that children are legitimate (wetting kind), namely children who are considered born from a legitimate marriage between father and mother. Thus, between the Civil Code and Islamic law, both consider that the legitimate basis of a child is the marriage of his parents. The big and profound differences occur when giving a calcification of what is said to be a legitimate child, because the Civil Code affirmed in the rules of Article 272 and Article 280 considers that a child born out of wedlock by a person who is not married marrying someone else, called a natural child, can be used as a legitimate child or a legitimate child. In this case according to Islamic law, the child is still considered an illegitimate child (child of adultery). ${ }^{14}$

\section{The definition of a child is illegal according to the Civil Code and according to Islamic Law}

Illegal children according to the Civil Code are known as zina children and discordant children. Both types of children cannot be recognized and ratified at all, this is based on affirmation of the rules Article $253 \mathrm{BW}$ says that

13 Moh. Dliya'ul Chaq. Nasab Anak Dalam Hukum Islam: Membaca Peluang Sains Dan Teknologi Dalam Penetapan Nasab. Tafaqquh: Jurnal Penelitian Dan Kajian Keislaman. Volume 6 Nomor 1 Juni 2018, 60-76, p. 70

14 Edo Febriansyah. Tinjauan Yuridis Putusan Mahkamah Konstitusi Nomor 46/PUU-VIII/2010 Tentang Kedudukan Anak Diluar Nikah Yang Diakui Dalam Pembagian Warisan. Unnes Law Journal. Volume 4 Nomor 1 Juni 2015, 1-19, p. 17 
based on adultery, a husband can deny the validity of a child. Furthermore, in affirming the rules of Article $283 \mathrm{BW}$, it is stated that the child who is cultured in adultery or donation can never be ratified. ${ }^{15}$

Based on the two articles above, to obtain clarity regarding zina children according to the civil code, legal experts provide a definition of understanding. According to Ali Afandi, zina children are "children born to a woman or given to a man, while a woman or a man is in marriage with someone else, while a child born in a donation is a child born to a mother, who is prohibited from marrying according to the law - invite with the man who gave the child the treatment". While J. Satrio said that "Adultery children are children born from a relationship between two men and women, who are not husband and wife where one or both are bound in a marriage with another person". Whereas the discordant child is "the child born of the relationship between two people who have close blood relations, so that between the two is prohibited by the law of marriage". ${ }^{16}$

The child is illegitimate according to Islamic Law known as the child of adultery, as stated in the hadith of the Prophet Muhammad: "From Ruaifi bin Tsabit, from the Prophet said: it is not one who believes in Allah SWT the day after (the end), if he (male) splash the water (supermanya) on other people's plants (the womb of another's child)". Based on the history of this hadith, the scholars have given an understanding of persecuting adultery children, including Sayyid Sabiq arguing that "Adultery children are, children born without the marital ties that Islam advocates". Furthermore Musyfuk Zuhdi suggests that "adultery children are children born outside of legal marriage". ${ }^{17}$

From the understanding expressed by the scholars, it can be concluded that, as long as the child is born or brought forth not as a result of a legitimate marriage, then the child cannot be said to be a legitimate child. Thus civil law and Islamic law recognize the existence of illegitimate children. So in formal juridical terms zina children are seen as illegitimate and deemed unable to use their rights to sue as legitimate children. ${ }^{18}$ The similarity of views between BW and Islamic law, there are also differences in terms of establishing adultery children, because the BW law only recognizes the existence of adultery

15 Muhamad Arifin. KEDUDUKAN ANAK LUAR KAWIN: Analisis Putusan Mahkamah Konstitusi No. 46/PUUVIII/ 2010 Tentang Uji Materi Terhadap Pasal 43 Ayat 1 UU No. 1 Tahun 1974 Tentang Perkawinan. AHKAM: Jurnal Hukum Islam. Volume 5 Nomor 1 Tahun 2017, 117-138, p. 128

16 Agussalim Andi Gadjang. Op.Cit., p. 1230

17 Agussalim Andi Gadjang. Ibid., p. 1231

18 Sari Pusvita. Keperdataan Anak Diluar Nikah dalam Putusan Mahkamah Konstitusi dan Implikasinya terhadap Harta Warisan. Ulul Albab: Jurnal Studi dan Penelitian Hukum Islam. Volume 1 Nomor 2 April 2015, 31-51, p. 34 
children, if someone who has intercourse has been bound in a marriage with someone else. Whereas according to Islamic law as long as the relationship or intercourse is carried out between a woman and a man without a legal marriage, the relationship is called zina, which results in the birth of a child who cannot be recognized as a legitimate child. ${ }^{19}$

\section{Relationship of Adultery with His/Her Parents \\ 1. Relationship between adultery children and their parents according to the Civil Code}

The maintenance and provision of livelihood is not limited to legitimate children, but is no exception, whether he is a legitimate child, or an illegitimate child, as stipulated in the Law of the Republic of Indonesia Number 4 of 1979 concerning child welfare, especially in affirmation the rule of Article 8, states that: "Assistance and services aimed at realizing child welfare are the rights of every child without gender, religion, political establishment, and social position". From the above information regarding the relationship of parental responsibility to their children giving understanding that how important it is to provide protection for children in fostering their survival to fulfill their future.

Viewed from the aspect of child protection from differences, it creates problems for children, therefore out of wedlock children who are not recognized by their fathers get something that is not the same treatment in society compared to the rights of a legitimate child. Civil law or BW adheres to the principle that the child outside the new marriage has a relationship with the person of the master, after acknowledging the child. This can be seen in the Civil Code, especially in the rules of Article 280, which states that, with the recognition of a child out of wedlock, a civil relationship arises between the child and his father or mother. ${ }^{20}$

From the information above, it is clear that it is possible that a juridical child may not be born with a father or a mother, that is, in the case of neither the father nor the mother neglecting to acknowledge the child out of wedlock. But in reality a child has a biological father, that is, a man who causes a pregnant woman (childbirth). Furthermore, illegitimate children, who are not recognized by their masters, such as adultery children and discordant children do not give them civil rights relations, but only give as much as possible until the child becomes an adult or has the ability to finance himself. ${ }^{21}$

19 Ardian Arista Wardana. Pengakuan Anak Diluar Nikah: Tinjauan Yuridis Tentang Status Anak Diluar Nikah. Jurnal Jurisprudence. Volume 6 Nomor 2 September 2016, 160-165, p. 163

20 Busman Edyar. Op.Cit., p. 20

21 Moh. Dliya'ul Chaq. Op.Cit., p. 75 
The family legal position of children is given because zina is arranged in the first Civil Code (BW) title XII book about people. Judging from the reality that exists for children born as a result of adultery carried out is not sanctioned by legislation in force in the territory of Indonesia, such children do not have civil legal civil relations, both their families and their families. Party of his father. This can be seen in the Civil Code of the BW, in the rules of Article 272 and Article 283 as stated earlier, that children who are cultured or born due to adultery may not receive recognition or ratification by their masters. If it turns out that there is an acknowledgment, the confession is completely null and void, and there is absolutely no legal effect so that the cancellation can be requested by everyone even though the acknowledgment is not denied. So thus it is clear that the existence of zina children according to the Civil Code is very sad. ${ }^{22}$

\section{Relations between adultery children and their parents according to Islamic law}

The relationship between parents power over their children in Islamic law is carried out by parents as long as the child is not yet mature at the time of his union or divorce. Asf A. A. Fyzee said that a father is obliged to take care of his son until the time he reaches the balance, and his daughter is married. He is also responsible for maintaining his widowed or divorced daughter. The father is not obliged to provide for underage children who refuse to live together with him without proper reasons, as well as unmarried girls who have no right to earn such a living, thus justifying the child to live in his own care place, except if other circumstances . But the father's obligation is not lacking because the child is in his mother's care. Boys who have grown up do not need to be given a living unless they are sick. ${ }^{23}$

Judging from the obligation of parents to their children, that he plays an important role in his family, therefore there are two kinds of fathers responsibilities towards his family, namely: 1). the father functions as the person in charge of the family; 2). Father as a family care and protector. So it is clear that living is the duty of the father for his children who have not been able to maintain their welfare and safety, whether the child is a legitimate child or illegitimate child, he has the right to pay for his living expenses, maintenance and education according to ability of his parents.

In terms of family relations, of course this kind of child is not as good as his fate with legitimate children, especially in terms of his inheritance

22 Dzanurusyamsi. Upaya Pengadilan Dalam Perlindungan Anak Luar Nikah Berdasarkan Sila Ke-5 Pancasila. Jurnal Pembaharuan Hukum. Volume 3 Nomor 1, April 2016, 86-97, p. 90

23 Agussalim Andi Gadjang. Op.Cit., p. 1228 
relationship. Regarding the kinship relationship of the child in Islamic law has been stated in the hadith of the Prophet SAW: "From Abu Hurairah, Rasullulah Saw, said: the child is the right of the person who is as happy as him and for those who deny there is no right" (H.R. Al-Jamaah except Abu Daud). This hadith provides a broad understanding that if there is a husband whose wife commits adultery with another man then becomes pregnant, then the baby he conceives is his husband's child if he acknowledges it, not for the man who abuses him. If the husband does not recognize the child there is no right for him, both kinship and inheritance, the child is only connected to his mother. ${ }^{24}$

\section{Conclusion}

From the description stated in this paper, it can be concluded that zina children are legitimate children outside of marriage or who were born before age at least 180 days after the implementation of marriage, both according to Civil Code (BW) and according to Islamic law. Children born outside of marriage according to BW can be recognized and endorsed by their parents and as a result of ratification and recognition there arises a civil relationship with parents and their family.

According to Civil Law (KUH Perdata) and Islamic law the legitimate denial of children can result in the breakup of marriage making the child an illegitimate child and not having an inheritance relationship with his parents, but his mother according to Islamic law. If the child of adultery is associated with obligations and responsibilities regarding survival, then the parents or fathers are still charged with the obligation to provide a living. As the cost of living and the cost of their education as needed or according to their abilities, because he is the biological father of the child. If the status of the adultery child is associated with inheritance according to $\mathrm{BW}$, then he does not inherit at all to his/her parents. But if it is associated with Islamic inheritance, then he inherits only his mother and his mother's family.

\section{Bibliograpy}

Ali Mohtaron. Kedudukan Anak Hasil Hubungan Zina Menurut Hukum Islam Dan Hukum Positif. Al-Murabbi: Jurnal Pendidikan Agama Islam. Volume 3 Nomor 2 Juni 2018, 193-203.

24 Agussalim Andi Gadjang. Op.Cit., p. 1231 
Imam Juhari. Legal Guardianshio Of Adultery Child And The Right Of Inheritence. Kanun Jurnal Ilmu Hukum, Nomor 4 Agustus 2011, 1-20.

Agussalim Andi Gadjang. Kedududkan Anak Di luar Pernikahan Menurut KUH Perdata dan Menurut Hukum Islam. Junal Asy-Syir'ah. Volume 45 Nomor 1 tahun 2011, 1221-1234.

Ardian Arista Wardana. Pengakuan Anak Diluar Nikah: Tinjauan Yuridis Tentang Status Anak Diluar Nikah. Jurnal Jurisprudence. Volume 6 Nomor 2 September 2016, 160-165.

Busman Edyar. Status Anak Luar nikah Menurut Hukum Positif dan Hukum Islam Pasca Keluarnya Putusan MK Tentang Uji materiil Undang Undang Perkawinan. Al Istinbath: Jurnal Hukum Islam. Volume 1 Nomor 2 Tahun 2016, 1-28.

Dzanurusyamsi. Upaya Pengadilan Dalam Perlindungan Anak Luar Nikah Berdasarkan Sila Ke-5 Pancasila. Jurnal Pembaharuan Hukum. Volume 3 Nomor 1, April 2016, 86-97.

Edo Febriansyah. Tinjauan Yuridis Putusan Mahkamah Konstitusi Nomor 46/PUU-VIII/2010 Tentang Kedudukan Anak Diluar Nikah Yang Diakui Dalam Pembagian Warisan. Unnes Law Journal. Volume 4 Nomor 1 Juni 2015, 1-19.

Maria Ulfah. Wanita Hamil Di Luar Nikah (Status Anak). Jurnal Pembaharuan Hukum. Volume 2 Nomor 3 Desember 2015, 329-335.

Moh. Dliya'ul Chaq. Nasab Anak Dalam Hukum Islam: Membaca Peluang Sains Dan Teknologi Dalam Penetapan Nasab. Tafaqquh: Jurnal Penelitian Dan Kajian Keislaman. Volume 6 Nomor 1 Juni 2018, 60-76.

Muhamad Arifin. KEDUDUKAN ANAK LUAR KAWIN: Analisis Putusan Mahkamah Konstitusi No. 46/PUUVIII/2010 Tentang Uji Materi Terhadap Pasal 43 Ayat 1 UU No. 1 Tahun 1974 Tentang Perkawinan. AHKAM: Jurnal Hukum Islam. Volume 5 Nomor 1 Tahun 2017, 117-138.

Sari Pusvita. Keperdataan Anak Diluar Nikah dalam Putusan Mahkamah Konstitusi dan Implikasinya terhadap Harta Warisan. Ulul Albab: Jurnal Studi dan Penelitian Hukum Islam. Volume 1 Nomor 2 April 2015, 31-51. 